ISSN 1392-3196 / e-ISSN 2335-8947

Zemdirbyste-Agriculture, vol. 102, No. 3 (2015), p. 305-312

DOI 10.13080/z-a.2015.102.039

\title{
Chlorophyll $a$ fluorescence of perennial ryegrass (Lolium perenne L.) varieties under long term exposure to shade
}

\author{
Piotr DĄBROWSKI ${ }^{1}$, Bogumiła PAWLUŚKIEWICZ ${ }^{1}$, Aneta Helena BACZEWSKA ${ }^{2}$, \\ Paweł OGLĘCKI ${ }^{1}$, Hazem KALAJI ${ }^{1}$ \\ ${ }^{1}$ Warsaw University of Life Sciences \\ Nowoursynowska 159, 02-779 Warsaw, Poland \\ E-mail: piotr.andrzej.dabrowski@gmail.com \\ ${ }^{2}$ Polish Academy of Science Botanical Garden - Centre for Biological Diversity Conservation in Powsin \\ Prawdziwka 2, 02-973 Warsaw, Poland
}

\begin{abstract}
The perennial ryegrass is the species widely used in Europe as forage as well as for creating lawns in urban areas. Unfavourable light conditions in cities are the principal reason of improper growth and functioning of grass communities. The aim of our work was to answer the following questions: what is the adaptive ability of photosynthetic apparatus of perennial ryegrass varieties to long-term reduction of solar radiation and which of the tested varieties has the best properties to be used for grassland establishment under reduced light conditions. A two-factor experiment was conducted with three varieties and three shading variants. Measurements of chlorophyll $a$ fluorescence were provided, and the basic assessed parameters were: minimal fluorescence $\left(\mathrm{F}_{0}\right)$, maximal fluorescence $\left(\mathrm{F}_{\mathrm{m}}\right)$, variable fluorescence $\left(\mathrm{F}_{\mathrm{v}}\right)$ and maximal photosynthetic efficiency of photosystem II $\left(\mathrm{F}_{\mathrm{v}} / \mathrm{F}_{\mathrm{m}}\right)$. Gas exchange was also measured. We explored the differences between the selected varieties in terms of their photosynthetic apparatus adaptation to light conditions. During May, all varieties were characterized by increase in minimal and maximal fluorescence levels under reduced light. The most significant changes were noticed for variety 'Taya'. During following months, a trend of decline in photosynthetic efficiency was observed for this variety. For this variety the most significant changes of $\mathrm{CO}_{2}$ were also noted. The stomatal conductance was not affected by shading. On the basis of our results, we have assumed that each variety is unique in terms of threshold values and demand for light.
\end{abstract}

Key words: chlorophyll $a$, grasses, green infrastructure, lawns, light, Lolium perenne, photosynthesis, unfavourable light conditions.

\section{Introduction}

The perennial ryegrass (Lolium perenne L.) is one of the most popular grass species in Europe. It is widely used as a forage crop and as alternative and renewable bioenergy source (Jonavičienė et al., 2014). The lawn varieties of perennial ryegrass are commonly used for establishing of lawns in urban areas (Dąbrowski et al., 2013).

The urban green areas have multiple functions. Well-kept lawns enhance the aesthetic value of the entire city and they are involved in phytoremediation, which leads to improvement in the quality of air and soil (Wołejko et al., 2014). It was the reason of increasing, in recent decades, the demand for amenity grasses for ornamental lawns, grasslands, green areas in parks and for sports turf. Plant growth is hindered by various abiotic stresses - water deficit, light, heat and salt. The light conditions in urban areas are substantially modified by technical structures and trees, which leads to deterioration of the grass communities. Under such conditions, the amount of solar energy is reduced, and the wavelength spectrum is modified (Bell et al., 2000). In sporting arenas the shade is a significant factor correlated with the loss of grass cover to the turf and with algal invasion (van Huylenbroeck et al., 1999). In the parks and ornamental lawns, shade is most frequently combined with drought stress as a result of competition with trees and shrubs. The first physiological symptoms of negative impact of shade are reduction of the rate of photosynthesis and accumulation of pigments (van Huylenbroeck et al., 1999). The first morphological signs are leaf elongation and decreasing in leaf coverage. The results obtained by Gautier et al. (1998) suggest that the reduction of photon flux intensity had the significant impact on tillering of perennial ryegrass. Subsequently of photon flux intensity on grasses is the sodding reduction (Lewis, 2004). However, the effect of long-term reduction in the level of solar radiation, especially on functioning of the photosynthetic apparatus of lawn grasses in urban green areas, is still poorly recognized.

Photosynthetically active radiation (PAR) energy absorption by photosynthetic pigment molecules occurs in the antenna complexes located in the thylakoid membranes (Kalaji et al., 2012). The absorbed energy 
is then transferred as excitation energy to photosystem I (PSI) and photosystem II (PSII) reaction centre, where it is used to initiate photochemical reactions. A part of this energy is lost as heat and chlorophyll $a$ fluorescence. The chlorophyll $a$ fluorescence process can provide information on the functioning and structure of the photosynthetic apparatus (Kalaji, Łoboda, 2007; Akhkha et al., 2013; Stirbet et al., 2014; Živčák et al., 2014 a). Moreover, methods based on records of chlorophyll fluorescence are reliable, non-invasive, powerful and simple tools for assessment of photosynthetic electron transport (Živčák et al., 2014 b) and related photosynthetic processes and allow for detection of stress in plants (Baker, Rosenqvist, 2004; Borawska-Jarmułowicz et al., 2014). At the present time there is no research on the state of the photosynthetic apparatus in perennial ryegrass in terms of long term shading. The current research has focused on agricultural plants, such as lettuce (Fu et al., 2012), subterranean clover (Mauro et al., 2011), or wheat (Mitchell et al., 2006; Mu et al., 2010; Akhkha et al., 2013). Studies on the lawn varieties of perennial ryegrass were related only to drought and temperature stress (Borawska-Jarmułowicz et al., 2014), but there were no studies on the influence of unfavourable light conditions on perennial ryegrass lawn varieties. There was no attempt to select lawn varieties from this species, which could be used in unfavourable lighting conditions. The results obtained by Studer et al. (2008) showed that there was wide diversity within variety of perennial ryegrass in terms of response to habitat conditions.

Our work was conducted to answer the following question: what is the adaptive ability of the photosynthetic apparatus in the chosen varieties of perennial ryegrass to long-term reduction of solar radiation and which of the tested varieties have the best properties to be used for grassland establishment under unfavourable light conditions. The result will contribute to the development of grasslands in cities under diverse light intensity.

\section{Material and methods}

The experiment lasted from April 20, 2010 to September 24, 2012 and it was conducted at the vegetation hall at Warsaw Agricultural University $\left(52^{\circ} 259^{\prime} \mathrm{N}, 21^{\circ} 020^{\prime}\right.$ E), in a two-factor split-plot system. Each treatment was replicated three times in special boxes $(213 \times 107 \times 15 \mathrm{~cm})$ with a permeable bottom. Boxes were divided into 9 plots $\left(71 \times 35 \mathrm{~cm}\right.$ and an area of $\left.0.25 \mathrm{~m}^{2}\right)$. Two research factors were applied. The level of shade was the first one, expressed by quantity of solar irradiance $\left(\mathrm{W} \mathrm{m}^{-2}\right)$ : absence of shade sun (control), half shade and shade. The second factor was the lawn variety of perennial ryegrass (Lolium perenne L.). The study involved three varieties: 'Nira' (HBP Sp. zo.o., Poland), 'Henrietta' (Feldsaaten Freudenberger $\mathrm{GmbH}$ \& Co Kg, Germany) and 'Taya' (DLF-Trifolium Group, Denmark).

The level of shading was simulated by layers of agrotextiles, which were constantly spread on a wooden frame above the plants (at the height of $50 \mathrm{~cm}$ ). Solar irradiance was measured by a meter TM-206 (Tenmars, Taiwan). Measurements were performed once a month during the entire vegetation period in 2012, and once per hour between 7.00 and 17.00. Measurements of the light spectrum were also carried out using a spectrophotometer SpectraPen SP 100 (Photon Systems Instruments, Czech
Republic) in August. The results were presented in Figure 1.

Ground moisture and ground temperature were monitoring permanently, measurements were performed every hour around the clock by using a TDR (time domain reflectometry) technique. Device MIDL (multi interface data logger) was used with field probes model FP/mts. The results were presented in Figure 2.

The sward was mowed regularly during the study period: $6-8$ times during the vegetation period at the height of 4-5 cm, multi-components fertilizer Substral 100 was used at a dose of $30 \mathrm{~g} \mathrm{~m}^{-2}$, twice during the vegetation period $\left(132 \mathrm{~kg} \mathrm{ha}^{-1} \mathrm{~N}, 30 \mathrm{~kg} \mathrm{ha}^{-1} \mathrm{P}_{2} \mathrm{O}_{5}\right.$ and 66 $\mathrm{kg} \mathrm{ha}^{-1} \mathrm{~K}_{2} \mathrm{O}$ ), irrigated in the case of lack of precipitation with $3 \mathrm{~mm} \mathrm{~m}^{-2}$ dose per day.

A fluorimeter OS5p (Optisciences, Great Britain) was used to estimate the efficiency of the photosynthetic apparatus. The leaves were adapted in the darkness for 25 minutes. The intensity of the light pulse was $3500 \mu \mathrm{mol} \mathrm{m} \mathrm{m}^{2}$, and the wavelength was $650 \mathrm{~nm}$. Chlorophyll $a$ fluorescence was measured in the middle part of the flag leaf. The measured parameters were: minimal fluorescence $\left(\mathrm{F}_{0}\right)$, maximal fluorescence $\left(\mathrm{F}_{\mathrm{m}}\right)$, variable fluorescence $\left(\mathrm{F}_{\mathrm{v}}\right)$ and maximum photosynthetic efficiency of PSII $\left(\mathrm{F}_{\mathrm{v}} / \mathrm{F}_{\mathrm{m}}\right)$. There were 9 replicates per treatment. Gas exchange measurements were carried out by LCpro+ (ACD Bioscentific Ltd., Great Britain) on the middle part of the attached flag leaf in 9 replicates. The chamber surface was $6.2 \mathrm{~cm}^{2}$. $\mathrm{CO}_{2}$ assimilation and stomatal conductance were the measured parameter.

Statistical analysis was performed by using software STATISTICA, version 10. Analysis of variance (ANOVA) was used to determine the significance of differences between the means, Fischer's test was used as post-hoc test with level of significance $\alpha=0.05$. The Pearson procedure with level of significance $\alpha=0.05$ was applied to calculate the correlation coefficient.

\section{Results}

In the minimal fluorescence $\left(F_{0}\right)$ parameter in perennial ryegrass variety 'Nira', differences were found only in the spring (May-June), but for varieties 'Henrietta' and 'Taya', growth in shade was greater also in the summer (Fig. 3). Variety 'Taya' was characterized by particularly large differences in $\mathrm{F}_{\text {p }}$ parameter. The values were $30-70 \%$ higher in the shade than in the sun and $8-27 \%$ higher than in the half shade. Moreover, values were $12-23 \%$ higher in the half shade than in the sun.

The maximal fluorescence $\left(F_{n}\right)$ parameter was dependent on light conditions from May to August (Fig. 4). There were no significant differences between $F_{m}$ values measured in the sun and in the half-shade for 'Nira' and 'Henrietta'. However, values measured for 'Nira' were significantly higher in the shade than in the half shade and in the sun (avg. 34\%) in May and June, but they were lower than in the half shade and in the sun in July (avg. 14\%). For 'Henrietta', $F_{m}$ values were usually higher in the shade than in the sun. In May, these values were higher by $50 \%$, in June - by $15 \%$, and in August - by $22 \%$. Response to the light conditions was even more visible in 'Taya' in comparison with 'Henrietta'. $F_{m}$ values were significantly higher in the shade and in the half shade than in the sun in May and August. In June and July $F_{m}$ values were similar in the sun and in the half 

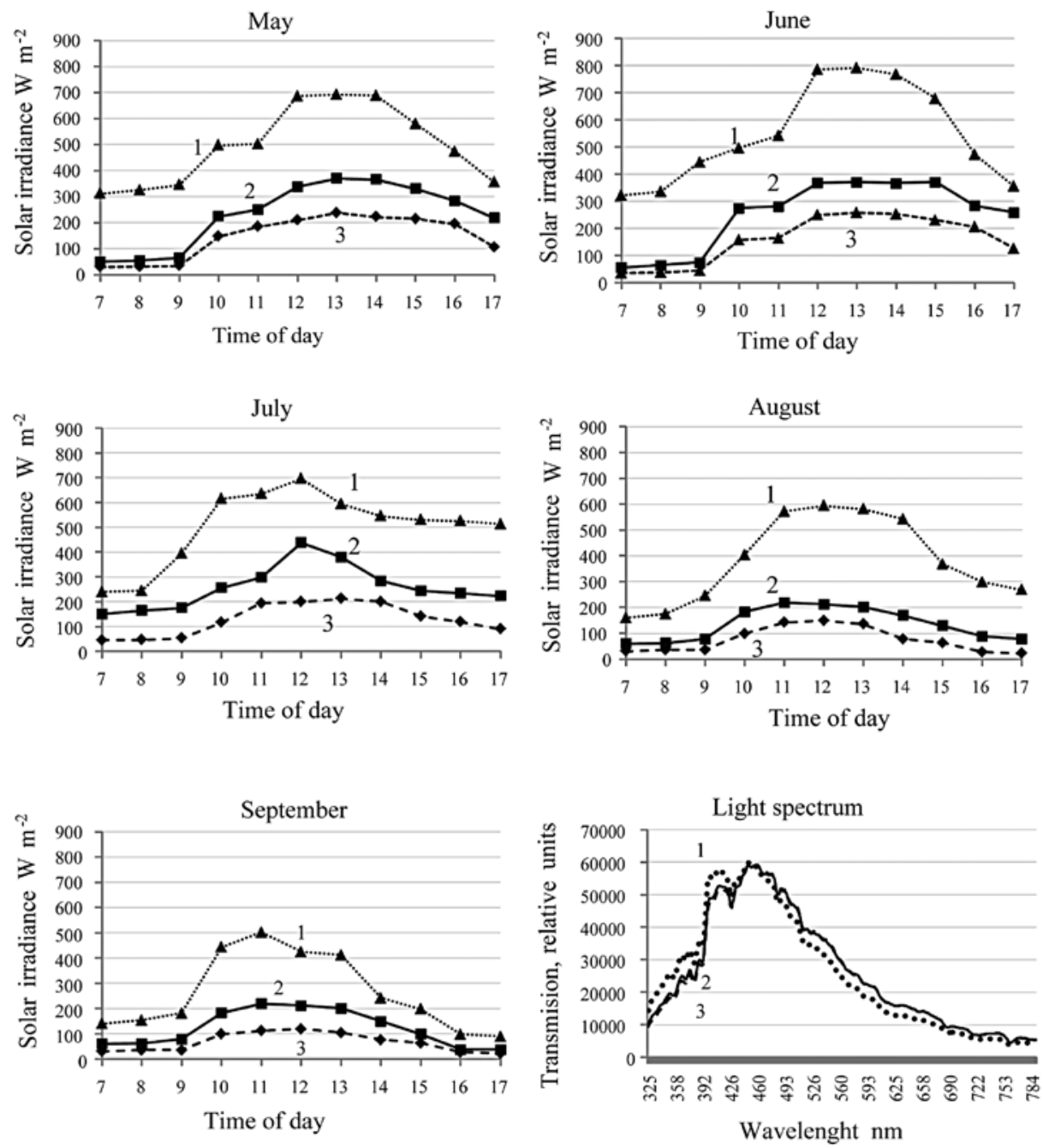

Note. Solar irradiance measured in May, June, July, August and September, and light spectrum - in August.

Figure 1. Light conditions in sun (1), half shade (2) and shade (3) treatments
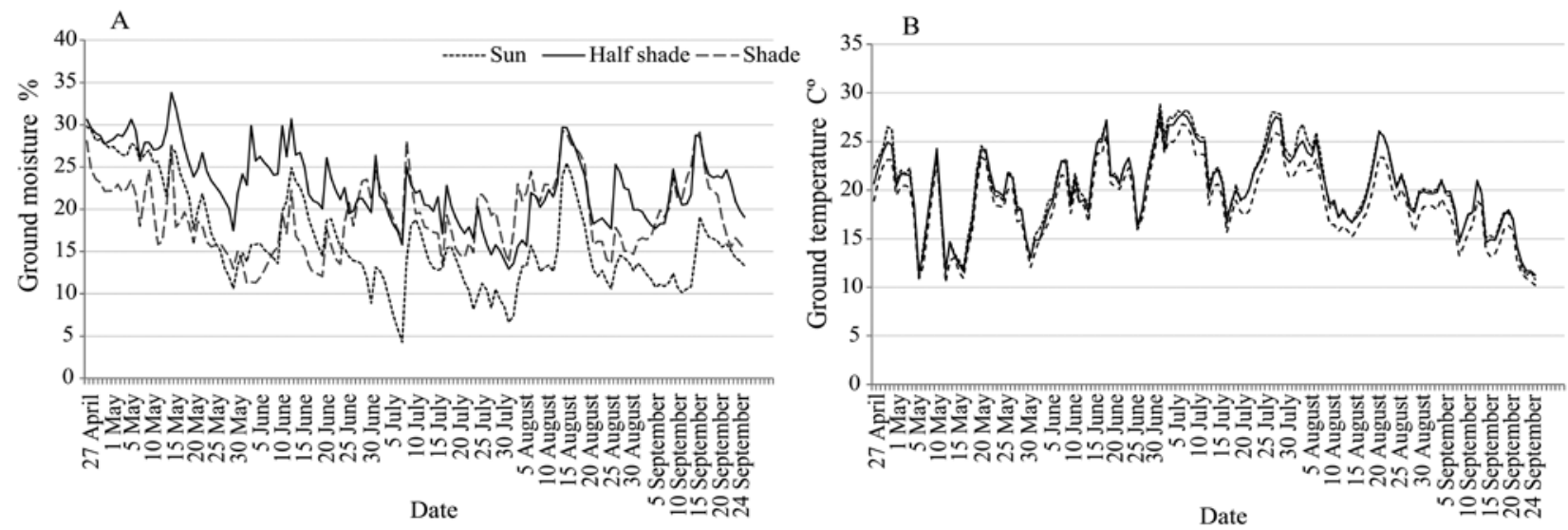

Figure 2. Ground moisture (A) and ground temperature (B) during experiment

shade, but were higher in the shade (in June - by $38 \%$ and in July - by $11 \%$ ).

Variable fluorescence $\left(F_{v}\right)$. In May and June, the tested varieties were characterized by lower values of that parameter in the sun and in the half shade than in the shadow (avg. 30\%) (Fig. 5). The reduced $F_{v}$ values under greater solar radiation in spring may indicate a lower activity of PSII and dissipation of excitation energy, most likely due to the higher air temperature in these treatments. In the summer months, the response to light conditions was differentiated in particular varieties. In July a stress reaction in 'Nira' growing in the shade was observed, but in 'Taya' stress response occurred in the sun $\left(F_{v}\right.$ was significantly lower in the sun than in the 

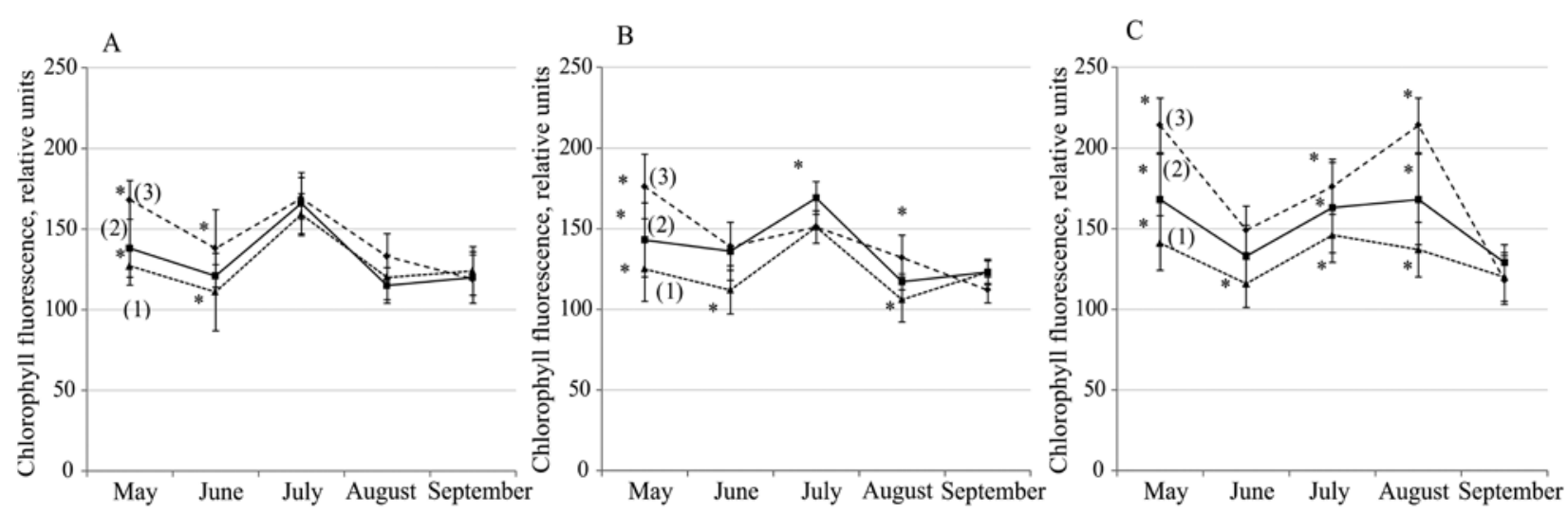

Note. The means marked by asterisks within one month and varieties differ significantly.

Figure 3. Minimal fluorescence $\left(\mathrm{F}_{0}\right)$ depending on light conditions: the sun (1), the half shade (2) and the shade (3) in varieties 'Nira' (A), 'Henrietta' (B) and 'Taya' (C) \pm SD
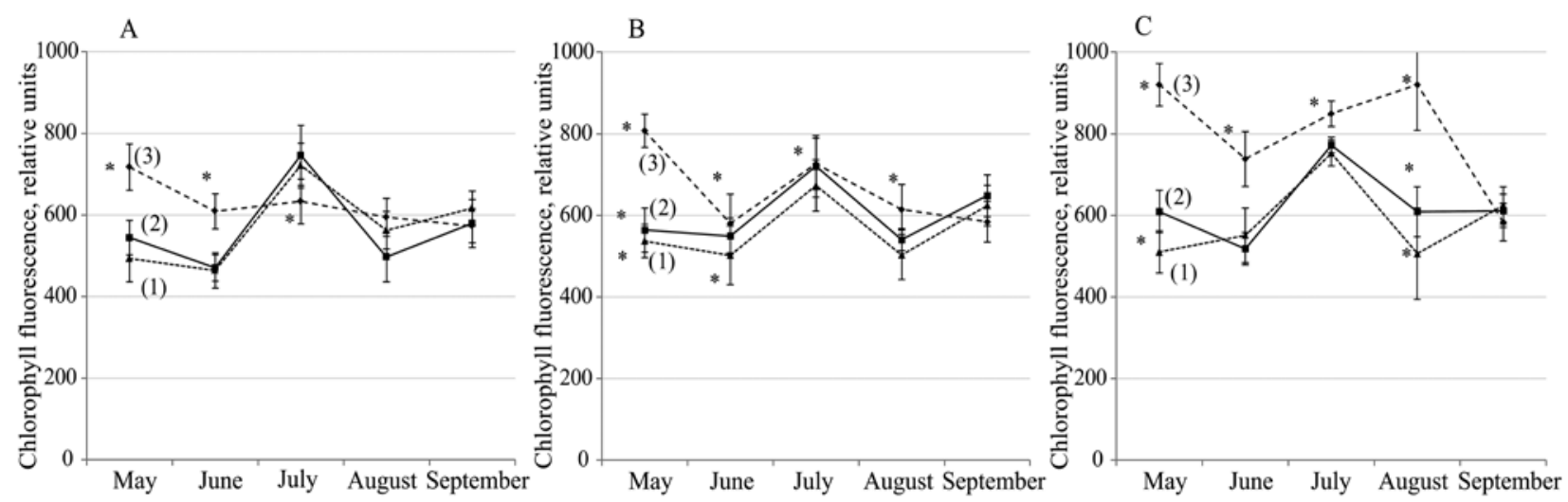

Note. The means marked by asterisks within one month and varieties differ significantly.

Figure 4. Maximal fluorescence $\left(\mathrm{F}_{\mathrm{m}}\right)$ depending on light conditions: the sun (1), the half shade (2) and the shade (3) in varieties 'Nira' (A), 'Henrietta' (B) and 'Taya' (C) \pm SD

A

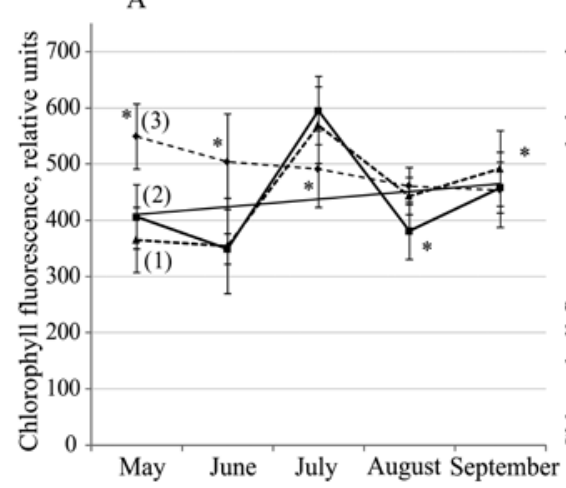

B

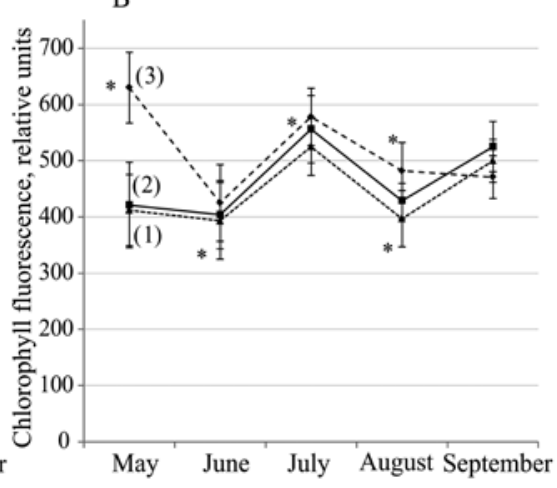

$\mathrm{C}$

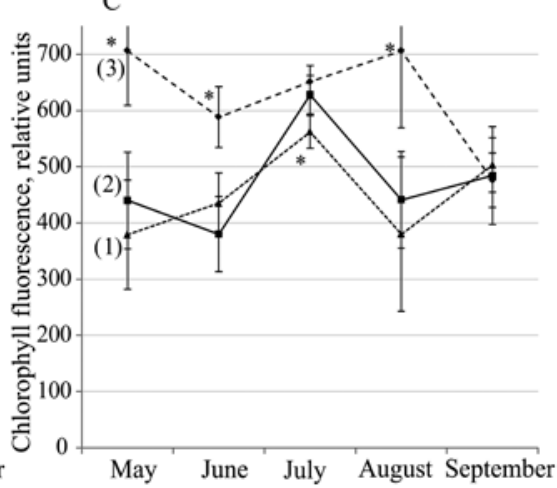

Note. The means marked by asterisks within one month and varieties differ significantly.

Figure 5. Variable fluorescence $\left(\mathrm{F}_{\mathrm{v}}\right)$ depending on light conditions: the sun (1), the half shade (2) and the shade (3) in varieties 'Nira' (A), 'Henrietta' (B) and 'Taya' (C) \pm SD shade). Irradiance had no significant effect on the value of this parameter in the variety of 'Henrietta'. In August, the smallest $F_{v}$ values in the sun were noticed in 'Henrietta', in 'Nira' - in the half shade, and in 'Taya' - in the sun and in the half shade. In September, all varieties were characterized by the lowest values in shade.

along with progress of vegetation to reach the level of 0.80 in September (Fig. 6). In May, all varieties showed the highest photochemical efficiency of their photosynthetic apparatus in the shade. In June, the plants in the half shade were characterized by the lowest $\mathrm{F}_{\mathrm{v}} / \mathrm{F}_{\mathrm{m}}$ values. In July and August $F_{v} / F_{m}$ depends more on variety. For 'Nira' it was the highest in the sun, in 'Taya' in the sun in July, but in the shade in August. No influence of the light intensity 
A

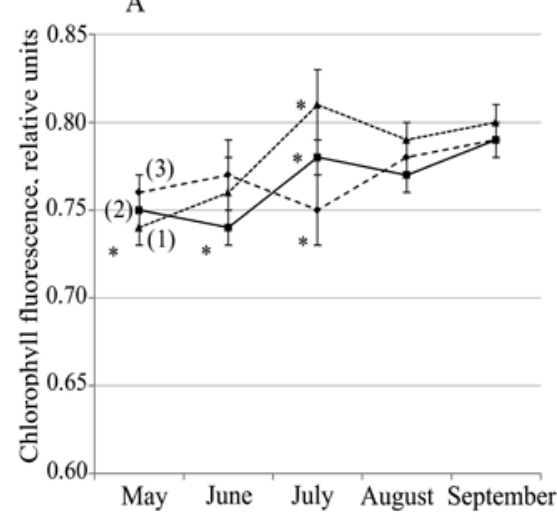

B

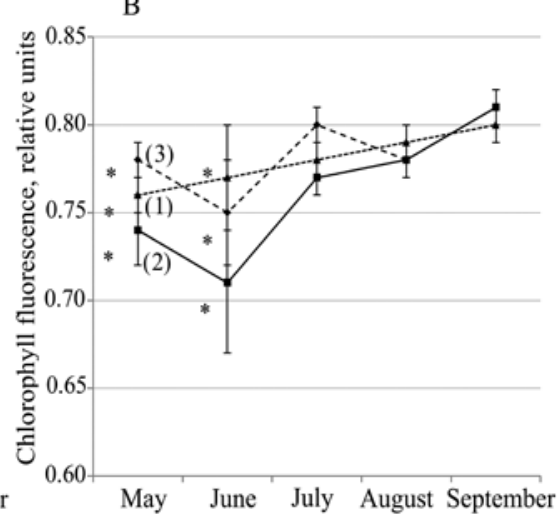

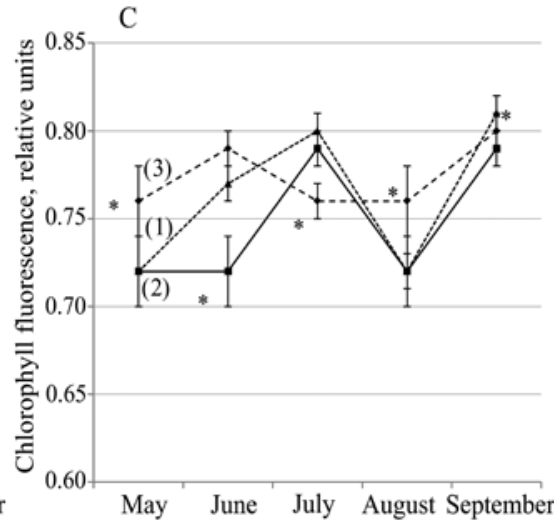

Note. The means marked by asterisks within one month and varieties differ significantly.

Figure 6. Maximal photosynthetic efficiency of PSII $\left(\mathrm{F}_{\mathrm{v}} / \mathrm{F}_{\mathrm{m}}\right)$ depending on light conditions: the sun (1), the half shade (2) and the shade (3) in varieties 'Nira' (A), 'Henrietta' (B) and 'Taya' (C) \pm SD

on $F_{v} / F_{m}$ values in 'Henrietta' was found. In September, the light conditions had no significant influence on $\mathrm{F}_{\mathrm{v}} / \mathrm{F}_{\mathrm{m}}$, excluding 'Taya'.

$\mathrm{CO}_{2}$ assimilation and stomatal conductance. In May, for varieties 'Nira' and 'Taya' grown in the sun, assimilation was at level of $20 \mu \mathrm{mol} \mathrm{CO} \mathrm{m}^{-2} \mathrm{~s}^{-1}$ and decreased to $5 \mu \mathrm{mol} \mathrm{CO} \mathrm{m}^{-2} \mathrm{~s}^{-1}$ (Fig. 7). $\mathrm{CO}_{2}$ assimilation was significantly lower in the half shade and in the shade than in the sun (by $46.3 \%$ in the half-shade and by $66.8 \%$ in the shade). The biggest difference between the sun and the shade was found in May, especially for 'Nira'. As opposed to 'Nira' and 'Taya', 'Hernietta' was characterized by lower $\mathrm{CO}_{2}$ assimilation in the spring months. The quantity did not exceed $10 \mu \mathrm{mol} \mathrm{CO}_{2} \mathrm{~m}^{-2}$ $\mathrm{s}^{-1}$ in the sun and $5 \mu \mathrm{mol} \mathrm{CO} \mathrm{CO}^{-2} \mathrm{~s}^{-1}$ in the half shade and the shade. The quantities of $\mathrm{CO}_{2}$ assimilation in other months were similar as in other varieties. Stomatal conductance values ranged from 0.06 to 0.08 mmol $\mathrm{H}_{2} \mathrm{O}$ $\mathrm{m}^{-2} \mathrm{~s}^{-1}$ (Fig. 8). There were no differences between the values measured under different light conditions.
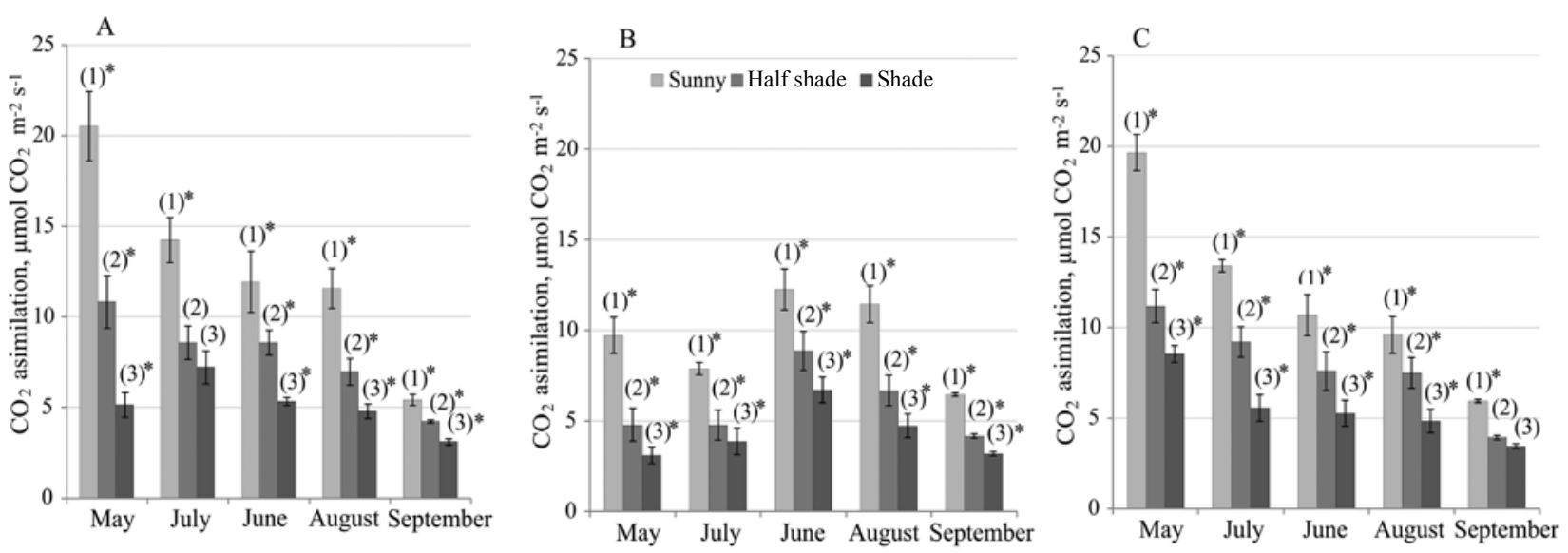

Note. The means marked by asterisks within one month and varieties differ significantly.

Figure 7. $\mathrm{CO}_{2}$ net assimilation in differing light conditions: the sun (1), the half shade (2) and the shade (3) in varieties 'Nira' (A), 'Henrietta' (B) and 'Taya' (C) \pm SD

The correlation coefficients between $\mathrm{CO}_{2}$ assimilation and chlorophyll $a$ fluorescence parameters are shown in Table. For 'Nira' in May, there was strongly negative correlation between $\mathrm{CO}_{2}$ assimilation and all measured parameters. In June, the correlation coefficients were statistically significant between $\mathrm{CO}_{2}$ assimilation and $\mathrm{F}_{0}, \mathrm{~F}_{\mathrm{m}}$ and $\mathrm{F}_{\mathrm{v}}$ parameters, but not for $\mathrm{F}_{\mathrm{v}} /$ $\mathrm{F}_{\mathrm{m}}(-0.24)$. In July, there was negative but not statistical significant correlation between $\mathrm{CO}_{2}$ assimilation and $\mathrm{F}_{0}$ parameter. For $\mathrm{F}_{\mathrm{m}}$ and $\mathrm{F}_{\mathrm{v}}$ the correlation was negative and statistically significant and for $\mathrm{F}_{\mathrm{v}} / \mathrm{F}_{\mathrm{m}}$ was positive and significant. In August and September, the statistically significant correlation was between $\mathrm{CO}_{2}$ assimilation and
$\mathrm{F}_{\mathrm{v}} / \mathrm{F}_{\mathrm{m}}$ parameters. For 'Henrietta' in May negative and significant differences were between $\mathrm{CO}_{2}$ assimilation and $\mathrm{F}_{0}, \mathrm{~F}_{\mathrm{m}}$ and $\mathrm{F}_{\mathrm{v}}$ parameters. In June, negative and significant differences were between $\mathrm{CO}_{2}$ assimilation and $\mathrm{F}_{0}$ and $\mathrm{F}_{\mathrm{m}}$ parameters, for $F_{v}$ was not significant and for $F_{v} / F_{m}$ was positive. The correlation coefficient was significantly positive for $\mathrm{F}_{\mathrm{v}} / \mathrm{F}_{\mathrm{m}}$ parameter in July and in August as well. For the other parameters it was significantly negative in August. In September, the correlation coefficient was positive for all of parameters but significant only for $\mathrm{F}_{\mathrm{v}} / \mathrm{F}_{\mathrm{m}}$ parameter. In 'Taya' in May, the correlation coefficient was significant negative between $\mathrm{CO}_{2}$ assimilation and all of measured parameters. In June, the correlation 

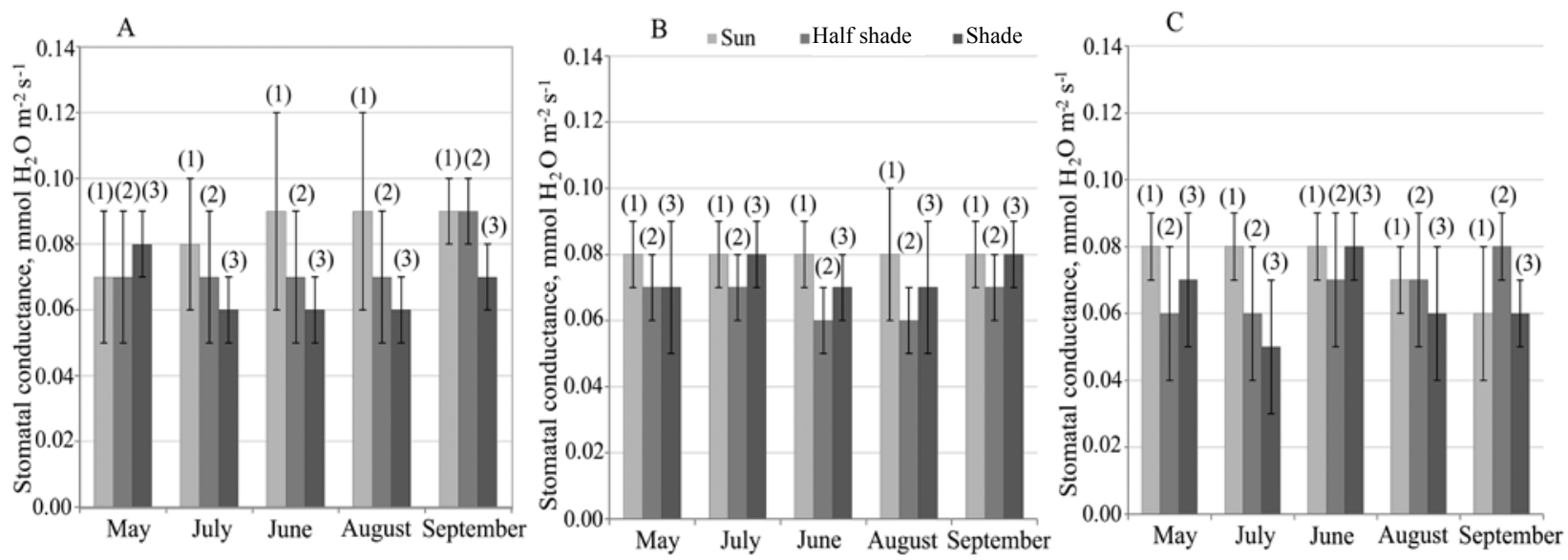

Note. The means marked by asterisks within one month and varieties differ significantly.

Figure 8. Stomatal conductance in differing light conditions: the sun (1), the half shade (2) and the shade (3) in 'Nira' (A), 'Henrietta' (B) and 'Taya' (C) $\pm \mathrm{SD}$

Table. Correlation coefficient between $\mathrm{CO}_{2}$ assimilation and chlorophyll $a$ fluorescence parameters in different months

\begin{tabular}{|c|c|c|c|c|c|}
\hline \multirow{2}{*}{ Variety } & \multirow{2}{*}{ Month } & \multicolumn{4}{|c|}{ Chlorophyll $a$ fluorescence parameters } \\
\hline & & $\mathrm{F}_{0}$ & $\mathrm{~F}_{\mathrm{m}}$ & $\mathrm{F}_{\mathrm{v}}$ & $\mathrm{F}_{\mathrm{v}} / \mathrm{F}_{\mathrm{m}}$ \\
\hline \multirow{5}{*}{ 'Nira' } & May & $-0.58^{*}$ & $-0.67^{*}$ & $-0.68^{*}$ & $-0.91 *$ \\
\hline & June & $-0.39^{*}$ & $-0.55^{*}$ & $-0.41 *$ & -0.24 \\
\hline & July & -0.29 & $-0.46^{*}$ & $0.45^{*}$ & $0.66^{*}$ \\
\hline & August & -0.29 & -0.41 & 0.02 & $0.66^{*}$ \\
\hline & September & 0.02 & 0.03 & 0.03 & $0.85^{*}$ \\
\hline \multirow{5}{*}{ 'Henrietta' } & May & $-0.61^{*}$ & $-0.58^{*}$ & $-0.56^{*}$ & -0.20 \\
\hline & June & $-0.67 *$ & $-0.42 *$ & -0.22 & $0.49 *$ \\
\hline & July & -0.10 & -0.23 & -0.26 & $0.89^{*}$ \\
\hline & August & $-0.78^{*}$ & $-0.70^{*}$ & $-0.68 *$ & $0.83 *$ \\
\hline & September & $0.38^{*}$ & 0.11 & 0.14 & $0.85^{*}$ \\
\hline \multirow{5}{*}{ 'Taya' } & May & $-0.72^{*}$ & $-0.69^{*}$ & $-0.68^{*}$ & $-0.91 *$ \\
\hline & June & $0.59^{*}$ & $-0.53 *$ & $-0.50 *$ & -0.22 \\
\hline & July & $-0.62^{*}$ & $-0.60 *$ & $-0.56^{*}$ & $0.95^{*}$ \\
\hline & August & $-0.63^{*}$ & $-0.67 *$ & $-0.68^{*}$ & $-0.88^{*}$ \\
\hline & September & 0.16 & 0.27 & 0.21 & $0.69 *$ \\
\hline
\end{tabular}

Note. The coefficient values marked by asterisk are significant.

coefficient was significant positive between $\mathrm{CO}_{2}$ assimilation and $\mathrm{F}_{0}$, between $\mathrm{CO}_{2}$ assimilation and $\mathrm{F}_{\mathrm{m}}^{2}$ and $\mathrm{F}_{\mathrm{v}}$ was negative. In July, the correlation coefficient was negative between $\mathrm{CO}_{2}$ assimilation and $\mathrm{F}_{0}, \mathrm{~F}_{\mathrm{m}}$ and $\mathrm{F}_{\mathrm{v}}$, but between $\mathrm{CO}_{2}$ assimilation and $\mathrm{F}_{\mathrm{v}} / \mathrm{F}_{\mathrm{m}}$ was positive. In August, the correlation coefficient was negative for all chlorophyll $a$ fluorescence parameters and in September was positive for $\mathrm{F}_{\mathrm{v}} / \mathrm{F}_{\mathrm{m}}$.

\section{Discussion}

Sunlight is known to be one of the most powerful factors influencing plant growth and development. It determines not only the physiological, but also the morphological variations of the leaves. In this study, it was found that the significance of the impact of the shading level depended on both, the variety and the season. $\mathrm{F}_{0}$ may be measured when all reaction centres are open and $\mathrm{Q}_{\mathrm{A}}$ (plastoquinones located on $\mathrm{D} 2$ protein) is fully oxidized. The increase in the $F_{0}$ parameter is explained by loss of PSII reaction centres (Fu et al., 2012) and their inactivation (Cui et al., 2006). According to these authors, the value of this parameter is also correlated with chlorophyll content, which increases in the shade (Cavagnaro, Trione, 2007; Mauro et al., 2011). $F_{m}$ may be detected when all centres are closed $\left(Q_{A}\right.$ fully reduced). This parameter showed a trend similar to $F_{0}$. Sarijeva et al. (2007) have proved a strong correlation of both parameters in plant leaves under different light treatment. Trend in changes of both parameters suggests the occurrence of photo-acclimation response of plants to shading, which has evolved to maximize light capture under unfavourable light conditions (Mauro et al., 2011; Reed et al., 2012). Variable fluorescence $\left(F_{v}\right)$ is the difference between the value of fluorescence parameters $\mathrm{F}_{\mathrm{m}}$ and $\mathrm{F}_{0}$ and depending on maximum quantum efficiency of PSII. The low values of this parameter is evidence of low PSII activity and dissipation of excitation energy as heat. $\mathrm{F}_{\mathrm{v}} / \mathrm{F}_{\mathrm{m}}$ is a reliable parameter to estimate the photochemical activity of PSII, and under stress-free conditions, it should be close to 0.83 (Kalaji et al., 2012). However, Mauro et al. (2011) reported a strong correlation between this parameter and the level of shading. Our results did not confirm this relationship. 
Photoinhibition is probably the reason for lower values in the sun in May and June. The phenomenon of reduction of $\mathrm{F}_{\mathrm{v}} / \mathrm{F}_{\mathrm{m}}$ parameter in the sun has been confirmed by Pollastrini et al. (2011). Higher $\mathrm{CO}_{2}$ assimilation was observed in full sun by many authors (Mitchell et al., 2006; Sarijeva et al., 2007; Dai et al., 2009), but is also dependent on air temperature and wind. This is probably the reason for low values in September and fluctuation of correlation coefficient between $\mathrm{CO}_{2}$ assimilation and $\mathrm{F}_{\mathrm{v}} / \mathrm{F}_{\mathrm{m}}$ parameter. Mauro et al. (2011) suggest that decreasing of light intensity occurs at the expense of electron transport, photophorylation and carbon fixation components, resulting in the reduced ability of the leaf to assimilate $\mathrm{CO}_{2}$. Li et al. (2014) have reported that under shading the decreased stomatal density, leaf thickness, cross-sectional area of the vascular bundle, contact area of the bundle sheath cells may be partially responsible for depressing photosynthetic capacity. The sun trapping leaves have a higher number of photosynthetic apparatus components providing the photosynthetic capability per unit of leaf area. The capacity of plants to adapt to shading was confirmed by (Miralles et al., 2011). Reed et al. (2012) have indicated that the entire photosynthetic apparatus in shade is more efficient at harvesting light, but it assimilates less $\mathrm{CO}_{2}$ in comparison with the leaves in the sun. This may be the reason for the lack of correlation between assimilation and the $\mathrm{F}_{\mathrm{v}} / \mathrm{F}_{\mathrm{m}}$ parameter (Table). Pollastrini et al. (2011) reported that stomatal conductance parameter was not affected by different light conditions, lack of this relationship and the fact that no such correlation exists have been confirmed by our results.

\section{Conclusion}

All varieties of perennial ryegrass showed the ability of photosynthetic apparatus to adapt to the longterm shading conditions. Varieties 'Nira' and 'Henrietta' displayed a comparable degree of adaptation to the shading, but 'Taya' showed higher adaptation ability, and this is variety recommended for establishment of lawns in shaded locations. Maximal photosynthetic efficiency of PSII $\left(\mathrm{F}_{\mathrm{v}} / \mathrm{F}_{\mathrm{m}}\right)$ is not a sufficient parameter to determine adaptability of the plants to shade. The correlation coefficient between this parameter and $\mathrm{CO}_{2}$ assimilation was changing during the whole season. At the beginning, the correlation was high positive, but it is necessary to analyze more parameters of the fluorescence induction curve, in particular, minimal $\left(\mathrm{F}_{0}\right)$, maximal $\left(\mathrm{F}_{\mathrm{m}}\right)$ and variable $\left(F_{v}\right)$ fluorescence.

Received 21012015

Accepted 10062015

\section{References}

Akhkha A., Boutraa T., Kalaji H., Ahmad P., Dąbrowski P. 2013. Chlorophyll fluorescence: a potential selection criterion for drought tolerance in selected durum wheat (Triticum durum Desf.) cultivars. NanoPhotoBioScences, 1: $147-156$

Baker N. R., Rosenqvist E. 2004. Applications of chlorophyll fluorescence can improve crop production strategies: an examination of future possibilities. Journal of Experimental Botany, 55: 1607-1621 http://dx.doi.org/10.1093/jxb/erh196
Bell G. E., Danneberger T. K., McMahon M. J. 2000. Spectral irradiance available for turfgrass growth in sun and shade. Crop Science, 40: 189-195

http://dx.doi.org/10.2135/cropsci2000.401189x

Borawska-Jarmułowicz B., Mastalerczuk G., Pietkiewicz S., Kalaji M. H. 2014. Low temperature and hardening effects on photosynthetic apparatus efficiency and survival of forage grass varieties. Plant, Soil and Environment, 60: 177-183

Cavagnaro J. B., Trione S. O. 2007. Physiological, morphological and biochemical responses to shade of Trichlores crinite, a forage grass from the arid zone of Argentina. Journal of Arid Environment, 68: 337-347 http://dx.doi.org/10.1016/j.jaridenv.2006.06.004

Cui X., Niu H., Wu J., Gu S., Wang Y., Wang S., Zhao X., Tang Y. 2006. Response of chlorophyll fluorescence to dynamic light in three alpine species differing in plant architecture. Environmental and Experimental Botany, 58: 149-157 http://dx.doi.org/10.1016/j.envexpbot.2005.07.004

Dai Y., Shen Z., Liu Y., Wang L., Hannaway D., Lu H. 2009. Effects of shade treatment on the photosynthetic capacity, chlorophyll fluorescence, and chlorophyll content of Tetrastigma hemsleyanum Diels et Gilg. Environmental and Experimental Botany, 65: 177-182 http://dx.doi.org/10.1016/j.envexpbot.2008.12.008

Dąbrowski P., Pawluśkiewicz B., Kalaji H. M., Baczewska A. H. 2013. The effect of light availability on leaf area index, biomass production and plant species composition of park grasslands in Warsaw. Plant, Soil and Environment, 59: 543-548

Fu W., Li P., Wu Y. 2012. Effects of different light intensities on chlorophyll fluorescence characteristic and yield in lettuce. Scientia Horticulturae, 135: 45-51 http://dx.doi.org/10.1016/j.scienta.2011.12.004

Gautier H., Varlet-Grancher C., Hazard L. 1998. Tillering responses to the light environment and to defoliation in populations of perennial ryegrass (Lolium perenne L.) selected for contrasting leaf length. Annals of Botany, 83: 423-429 http://dx.doi.org/10.1006/anbo.1998.0840

Jonavičienė K., Statkevičiūtè G., Kemešytė V., Brazauskas G. 2014. Genetic and phenotypic diversity for drought tolerance in perennial ryegrass (Lolium perenne L.). Zemdirbyste-Agriculture. 101 (4): 411-418 http://dx.doi.org/10.13080/z-a.2014.101.052

Kalaji H. M., Łoboda T. 2007. Photosystem II of barley seedlings growing under cadmium and lead stress. Plant, Soil and Environment, 53: 511-516

Kalaji H. M., Goltsev V., Bosa K., Allakhverdiev S. I., Strasser R. J., Govindjee. 2012. Experimental in vivo measurement of light emission in plants: a perspective dedicated to David Walker. Photosynthesis Research, 114: 69-96 http://dx.doi.org/10.1007/s11120-012-9780-3

Lewis G. C. 2004. Effects of biotic and abiotic stress on the growth of three genotypes of Lolium perenne with and without infection by the fungal endophyte Neotyphodium lolii. Annals of Applied Biology, 144: 53-63 http://dx.doi.org/10.1111/j.1744-7348.2004.tb00316.x

Li T., Liu L.-N., Jiang C.-D., Liu Y.-J., Shi L. 2014. Effects of mutual shading on the regulation of photosynthesis in field-grown sorghum. Journal of Photochemistry and Photobiology B: Biology. 137: 31-38 http://dx.doi.org/10.1016/j.jphotobiol.2014.04.022

Mauro R. P., Occhipinti A., Longo A. M. G., Mauromicale G. 2011. Effects of shading on chlorophyll content, chlorophyll fluorescence and photosynthesis of subterranean clover. Journal of Agronomy and Crop Science. 197: 57-66 http://dx.doi.org/10.1111/j.1439-037X.2010.00436.x

Miralles J., Martínez-Sánchez J. J., Francoa J. A., Bañón S. 2011. Rhamnus alaternus growth under four simulated shade environments: morphological, anatomical and physiological responses. Scientia Horticulturae, 127: 562-570 http://dx.doi.org/10.1016/j.scienta.2010.12.005 
Mitchell R., Gibbard C., Mitchell V., Lawlor D. 2006. Effect on shading in different developmental phases on biomass and grain yield of winter wheat at ambient and elevated $\mathrm{CO}_{2}$. Plant, Cell and Environment, 19: 615-621 http://dx.doi.org/10.1111/j.1365-3040.1996.tb00396.x

Mu H., Jing D., Wollenweber B., Dai T., Jing Q., Cao W. 2010. Long-term low radiation decreases leaf photosynthesis, photochemical efficiency and grain yield in winter wheat. Journal of Agronomy and Crop Sciences, 196: 38-47 http://dx.doi.org/10.1111/j.1439-037X.2009.00394.x

Pollastrini M., Di Stefano V., Ferretti M., Agati G., Grifoni D., Zipoli G., Orlandini S., Bussotti F. 2011. Influence of different light intensity regimes on leaf features of Vitis vinifera L. in ultraviolet radiation filtered condition. Environmental and Experimental Botany, 73: 108-115 http://dx.doi.org/10.1016/j.envexpbot.2010.10.027

Reed S., Schnell R., Moore M. J., Dunn C. 2012. Chlorophyll $a+b$ content and chlorophyll fluorescence in avocado. Journal of Agricultural Science, 4 (4): 29-36 http://dx.doi.org/10.5539/jas.v4n4p29

Sarijeva G., Knapp M., Lichtenthaler H. K. 2007. Differences in photosynthetic activity, chlorophyll and carotenoid level, and in chlorophyll fluorescence parameters in green sun and shade leaves of Ginko and Fagus. Journal of Plant Physiology, 164: 950-955 http://dx.doi.org/10.1016/j.jplph.2006.09.002

Stirbet A., Riznichenko A., Yu G., Rubin A. B., Govindjee. 2014. Modeling chlorophyll a fluorescence transient: relation to photosynthesis. Biochemistry (Moscow), 79: 291-323 http://dx.doi.org/10.1134/S0006297914040014
Studer B., Jensen L. B., Hentrup S., Brazauskas G., Kölliker R., Lübberstedt T. 2008. Genetic characterisation of seed yield and fertility traits in perennial ryegrass (Lolium perenne L.). Theoretical and Applied Genetics, 117: 781-791 http://dx.doi.org/10.1007/s00122-008-0819-y

van Huylenbroeck J. M., Lootens P., van Bockstaele E. 1999. Photosynthetic characteristics of perennial ryegrass and red fescue turf-grass cultivars. Grass and Forage Science, 54: $267-274$ http://dx.doi.org/10.1046/j.1365-2494.1999.00179.x

Wołejko E., Pawluśkiewicz B., Wydro U., Łoboda T., Butarewicz A. 2014. The effect of sewage sludge on the growth and species composition of the sward and the content of heavy metals in plant and urban soils. Annals of Warsaw University of Life Science - SGGW, Land Reclamation, 46: 101-114

Živčák M., Olšovská K., Slamka P., Galambošová J., Rataj V., Shao H. B., Brestič M. 2014 (a). Application of chlorophyll fluorescence performance indices to assess the wheat photosynthetic functions influenced by nitrogen deficiency. Plant, Soil and Environment, 60: 204-209

Živčák M., Olšovská K., Slamka P., Galambošová J., Rataj V., Shao H. B., Kalaji H. M., Brestič M. 2014 (b). Measurements of chlorophyll fluorescence in different leaf positions may detect nitrogen deficiency in wheat. Zemdirbyste-Agriculture, 101 (4): 437-444 http://dx.doi.org/10.13080/z-a.2014.101.056

ISSN 1392-3196 / e-ISSN 2335-8947

Zemdirbyste-Agriculture, vol. 102, No. 3 (2015), p. 305-312

DOI 10.13080/z-a.2015.102.039

\title{
Daugiametès svidrès (Lolium perenne $\mathrm{L}$.) veislių chlorofilo a fluorescencija ilgalaikio užpavèsinimo sąlygomis
}

\author{
P. Dąbrowski ${ }^{1}$, B. Pawluśkiewicz'1 A. H. Baczewska², P. Oglęcki ${ }^{1}$, H. Kalaji ${ }^{1}$ \\ ${ }^{1}$ Varšuvos gyvybès mokslų universitetas, Lenkija \\ ${ }^{2}$ Lenkijos mokslų akademijos Botanikos sodo Powsin biologinès įvairovès išsaugojimo centras
}

\section{Santrauka}

Daugiametė svidrè yra svarbus Europos pašarinis augalas (dèl šviesos trūkumo miestų vejos prastai auga). Tyrimo tikslas - nustatyti, kurios iš tirtų veislių pakančiausios silpnam apšvietimui, kokios yra daugiametės svidrès fotosintetinio aparato galimybės prisitaikyti prie ilgalaikès sumažintos saulès spinduliuotès. Trijų veislių daugiametės svidrès augintos esant trims užpavėsinimo variantams (dviejų veiksnių bandymas). Augalai buvo vertinti pagal chlorofilo a minimalią $\left(\mathrm{F}_{0}\right)$, maksimalią $\left(\mathrm{F}_{\mathrm{m}}\right)$ bei kintančią $\left(\mathrm{F}_{\mathrm{v}}\right)$ fluorescenciją ir II fotosistemos maksimalų fotosintetinị efektyvumą $\left(\mathrm{F}_{\mathrm{v}} / \mathrm{F}_{\mathrm{m}}\right)$ bei dujų mainus. Gegužès mènesị dèl sumažejusio apšvietimo augaluose minimali ir maksimali fluorescencija padidejo, ypač veislès 'Taya'. Vèlesniais mènesiais šios veislès svidrių fotosintetinis efektyvumas mažejo. Patys didžiausi $\mathrm{CO}_{2}$ pokyčiai taip pat buvo nustatyti šios veislès svidrių. Užpavėsinimas neturejo ịtakos žiotelių laidumui. Kiekviena tirta veislè pasižymèjo savitu šviesos stiprumo ir jo slenkstinių dydžių poreikiu.

Reikšminiai žodžiai: chlorofilas $a$, daugiametė svidrè, fotosintezè, nepalankios šviesos sąlygos, šviesa, vejos, žalioji infrastruktūra, žolès. 